\title{
(2) OPEN ACCESS \\ One ventilator for two patients: feasibility and considerations of a last resort solution in case of equipment shortage
}

\author{
Tommaso Tonetti $\odot,{ }^{1}$ Alberto Zanella, ${ }^{2,3}$ Giacinto Pizzilli,i, Charlene Irvin Babcock, ${ }^{5}$ \\ Sergio Venturi, ${ }^{6}$ Stefano Nava, ${ }^{7}$ Antonio Pesenti, ${ }^{2,3} \vee$ Marco Ranieri ${ }^{1}$
}

- Additional material is published online only. To view please visit the journal online (http://dx.doi.org/10.1136/ thoraxjnl-2020-214895).

For numbered affiliations see end of article.

\section{Correspondence to} Professor V Marco Ranieri; m.ranieri@unibo.it

TT, AZ and GP contributed equally.

TT, AZ and GP are joint first authors.

$\mathrm{SN}, \mathrm{AP}$ and VMR are joint senior authors.

Received 26 March 2020 Revised 31 March 2020 Accepted 1 April 2020 Published Online First 23 April 2020

\section{SLinked}

- http://dx.doi.org/10.1136/ thoraxjnl-2020-214929 - http://dx.doi.org/10.1136/ thoraxjnl-2020-214967

Check for updates

(C) Author(s) (or their employer(s)) 2020. Re-use permitted under CC BY-NC. No commercial re-use. See rights and permissions. Published by BMJ.

To cite: Tonetti T, Zanella A, Pizzilli G, et al. Thorax

2020:75:517-519.
The present emergency caused by the spread of the COVID-19 infection is putting enormous pressure on the healthcare systems worldwide and especially on intensive care units (ICUs).

One of the main fears in this regard is that we may run out of ventilators, a possibility which is getting more and more likely as the pandemic spreads throughout the world and the ICUs are overloaded with ventilated patients.

Many authors have already investigated the possibility of manipulating a ventilator circuit in order to ventilate up to four patients with a single machine. Neyman and Ervin first performed a bench study demonstrating the technical feasibility of ventilating four patients with one ventilator and one modified circuit. ${ }^{1}$ The same circuit configuration was used in 2008 by Paladino et al in an animal model, resulting in substantial differences in oxygenation and decarboxylation between subjects during the ventilation period. ${ }^{2}$ In 2012 Branson et al tested in vitro the Neyman and Ervin system simulating different conditions of compliance and resistance between the simultaneously ventilated test lungs. They observed wide variability in measured tidal volume $(\mathrm{Vt})$ and end-expiratory lung volume, so they concluded that the technique should be avoided because of potential danger. ${ }^{3}$ Accordingly, the authors argued that the stockpiling of ventilators should be the firstline solution when massive emergencies are forecast; only after their depletion, strategies such as the 'double circuit' should be implemented for the shortest possible duration. ${ }^{45}$

On 20 February 2020, the first case of COVID-19 emerged in the Lombardy region, northern Italy. As of 17 March, a total of 1069 patients had been admitted to ICUs in Lombardy, with a total of 1202 ICU beds available (after a significant expansion from the 720 beds available pre-crisis). ${ }^{6}$ By this time, a potential problem of ventilator shortages began to emerge because of the further spread of the virus in other regions of Italy. Great efforts have been put into place by institutions and industries to provide more ventilators for hospitals, but there is still a high potential for a supply-demand mismatch.

Therefore, we assembled, tested and proposed for production a simple circuit comprising tubing and accessories that are easily available in any intensive care/operating room setting. Indeed, one just needs two regular 'wye' breathing circuits, two ' $T$ ' connectors, and four heat and moisture exchanger
(HME) filters to build this system (see figure 1online supplementary file 1 , online supplementary file 2 ).

The two $T$ pieces are connected to the inspiratory and expiratory ports of the ventilator (figure 2). We preferred to interpose one HME filter in each expiratory limb (and not one for the entire expiratory circuit) in order to reduce total circuit resistance. At the end of each wye a patient is connected by interposing one HME filter. Total length of the tubing is $9.6 \mathrm{~m}$, and each patient can be located at $\sim 2 \mathrm{~m}$ from the ventilator.

We tested the circuit on a turbine ventilator (SIARETRON 4000 T, Siare Engineering International Group, Crespellano-Valsamoggia, Italy) connected by a two-patient circuit (Intersurgical SpA, Mirandola, Italy) to two test lungs (Model 5601 - Michigan Instruments Inc, Grand Rapids, MI, USA). We set ventilation for two patients of $80 \mathrm{~kg}$ of predicted body weight (PBW) targeting $6 \mathrm{~mL} / \mathrm{kg} \mathrm{Vt}$ at a respiratory rate (RR) of 20/min with an inspiratory: expiratory (I:E) ratio of $1: 1$ and a fraction of inspired oxygen $\left(\mathrm{FiO}_{2}\right)$ of $100 \%$. Positive end-expiratory pressure (PEEP) was set at $15 \mathrm{cmH}_{2} \mathrm{O}$ and initial inspiratory pressure (Pinsp) at $10 \mathrm{cmH}_{2} \mathrm{O}$. We performed an initial 15 hour test with similar conditions between the two simulated patients (static compliance of the respiratory system (Cstat) $50 \mathrm{~mL} / \mathrm{cmH}_{2} \mathrm{O}$ and airway resistance (Raw) $5 \mathrm{cmH}_{2} \mathrm{O} / \mathrm{L} / \mathrm{sec}$ ); in pressure control mode (Pinsp $11 \mathrm{cmH}_{2} \mathrm{O}$, PEEP $14 \mathrm{cmH}_{2} \mathrm{O}$, RR 20 beats/ min), measured delivered $\mathrm{Vt}$ was $953 \mathrm{~mL}$, while the patients received $470 \mathrm{~mL}$ each.

We then performed two more tests:

1. Different Cstat $\left(40 \mathrm{~mL} / \mathrm{cmH}_{2} \mathrm{O}\right.$ vs $60 \mathrm{~mL} / \mathrm{cm}$ $\mathrm{H}_{2} \mathrm{O}$ ) and equal Raw (5 $\left.\mathrm{cmH}_{2} \mathrm{O} / \mathrm{L} / \mathrm{sec}\right)$ : as expected, $\mathrm{Vt}$ distribution was proportional to Cstat $-540 \mathrm{~mL}$ for the simulated patient with Cstat $60 \mathrm{~mL} / \mathrm{cmH}_{2} \mathrm{O}$ and $340 \mathrm{~mL}$ for the one with Cstat $40 \mathrm{~mL} / \mathrm{cmH}_{2} \mathrm{O}$

2. Different Raw $\left(5 \mathrm{cmH}_{2} \mathrm{O} / \mathrm{L} / \mathrm{sec}\right.$ vs $20 \mathrm{cmH}_{2} \mathrm{O} / \mathrm{L} /$ sec) and equal Cstat $\left(50 \mathrm{~mL} / \mathrm{cmH}_{2} \mathrm{O}\right)$ : as expected, Vt distribution correlated with Raw$480 \mathrm{~mL}$ for Raw $5 \mathrm{cmH}_{2} \mathrm{O} / \mathrm{L} / \mathrm{sec}$ and $400 \mathrm{~mL}$ for Raw $20 \mathrm{cmH}_{2} \mathrm{O} / \mathrm{L} / \mathrm{sec}$.

Our tests confirm the in vitro technical feasibility of ventilating two patients with a single ventilator, but the difficulties and potential harm due to this configuration remain. Considering present knowledge on this issue and our data, we suggest a flow chart (table 1 ) to initiate this type of ventilation only in cases of extreme emergency due to machinery 


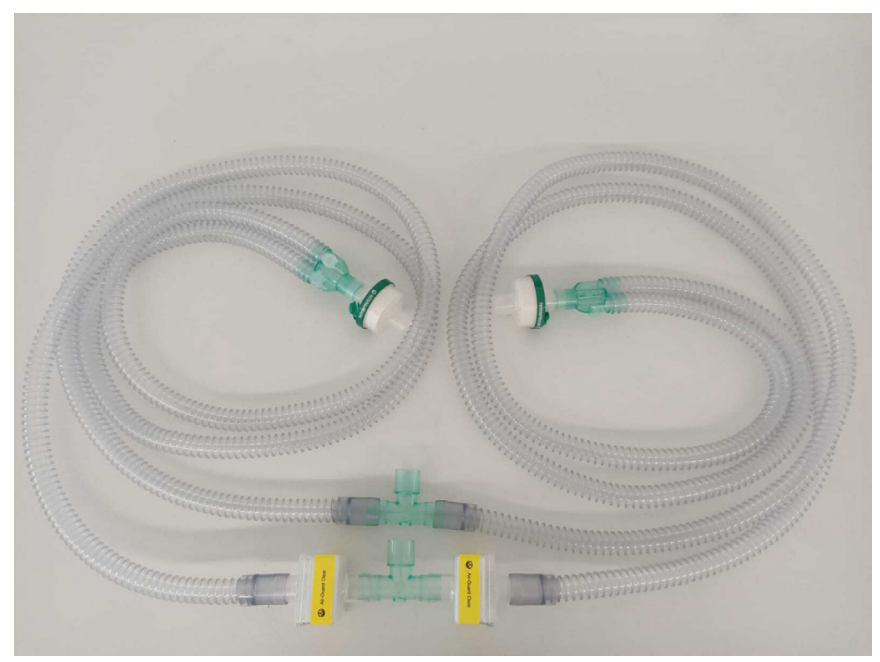

Figure 1 Assembled circuit.

shortages. A critical point is to match patients by compliance and, possibly, by airways resistance. Clinical personnel must remain vigilant, in order to recognise any possible sign of hypoor overventilation, and must be ready at any time to start manual bag ventilation if any issue would occur.

Compared with manual bag ventilation, our technique allows delivery of ventilation, PEEP and $\mathrm{FiO}_{2}$ with reasonable accuracy, is safer for operators and avoids the need for additional human resources (no 'human ventilator' is constantly needed at the patient's head). Using one ventilator for two patients instead of four (as proposed by some authors) reduces possible logistical issues (bed and ventilator positioning) and problems related to inadequate patient size matching.

We can conclude that this simple and easily built circuit can theoretically allow the emergency ventilation of two patients with a single ventilator. However, for a clinical application of this 'extreme' technique, several other factors must be taken into account. Indeed, anthropometric features (body weight and body mass index), respiratory mechanics (lung and chestwall compliances, airway resistances, possible auto-PEEP), physiological variables (complete paralysis, oxygen consumption and carbon dioxide production) and the clinical course of the two connected patients play a major role in determining the quality and quantity of ventilation delivered to each patient. Moreover, monitoring respiratory mechanics in each patient would be impossible

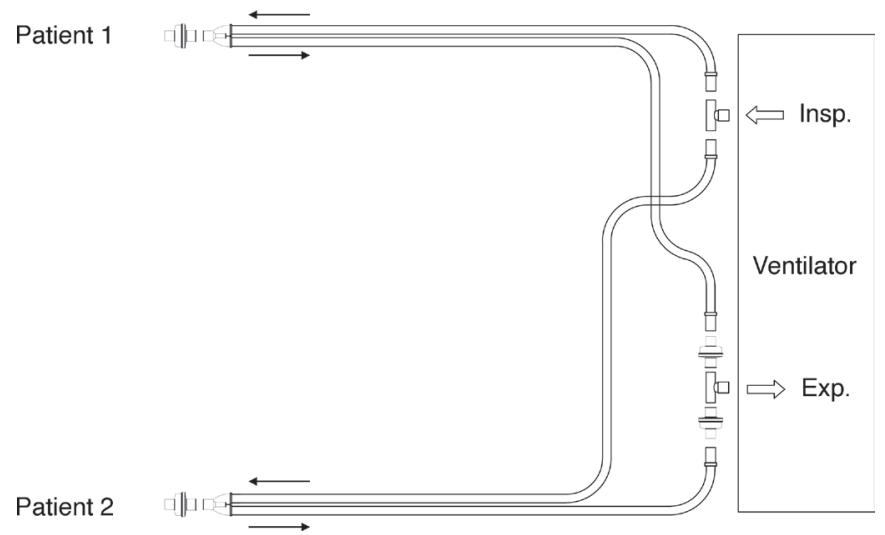

Figure 2 Circuit set-up. Arrows pointing left indicate inspiratory airflow, arrows pointing right indicate expiratory airflow. Insp., inspiratory port; Exp., expiratory port.
Table 1 Connecting two patients to one ventilator.

\begin{tabular}{|c|c|}
\hline Prerequisites: & $\begin{array}{l}\text { Emergency situation, no available ventilators } \\
\text { Mechanical ventilator with internal flow sensor } \\
\text { Double ventilation circuit } \\
\text { Passed leakage test } \\
\text { Double patient ventilation successfully simulated with } \\
\text { two test lungs/balloons in the desired ventilatory settings } \\
\text { range }\end{array}$ \\
\hline Settings: & $\begin{array}{l}\text { Set PCV and PEEP with driving pressure } \leq 15 \mathrm{cmH}_{2} \mathrm{O} \\
\text { Switch off inspiratory trigger }\end{array}$ \\
\hline Starting procedures: & $\begin{array}{l}\text { Connect first patient. } \\
\text { Assess Vt and lung mechanics (plateau pressure, static } \\
\text { compliance, total PEEP), maintaining the second wye } \\
\text { occluded } \\
\text { Connect second patient } \\
\text { Clamp first patient's ET during an expiratory hold and } \\
\text { perform lung mechanics assessment on second patient } \\
\text { (plateau pressure, static compliance, total } \mathrm{PEEP} \text { ) } \\
\text { Set longer inspiratory ramp time if desired } \mathrm{FiO}_{2} \text { cannot be } \\
\text { reached }\end{array}$ \\
\hline $\begin{array}{l}\text { Monitoring and } \\
\text { alarms: }\end{array}$ & $\begin{array}{l}\text { Set alarm on } \mathrm{Vt} \text { and } \mathrm{FiO}_{2} \text { at least } \\
\text { Monitor } \mathrm{SpO}_{2} \text { at least } \\
\text { - Monitor } \mathrm{EtCO}_{2} \text { whenever possible } \\
\text { - Perform } \mathrm{ABG}_{2} \text { regularly }\end{array}$ \\
\hline
\end{tabular}

Provide another ventilator as soon as possible

$\mathrm{ABG}$, arterial blood gas test; $\mathrm{ET}$, endotracheal tube; $\mathrm{EtCO}_{2^{\prime}}$ end-tidal carbon dioxide; $\mathrm{FiO}_{2}$, fraction of inspired oxygen ; PBW, predicted body weight; PCV, pressurecontrolled ventilation; $\mathrm{PEEP}$, positive end-expiratory pressure; $\mathrm{SpO}_{2^{\prime}}$, peripheral capillary oxygen saturation; $\mathrm{Vt}$, tidal volume.

or very difficult; however, we cannot neglect the possibility that, besides technical and physiological factors, ethical dilemmas may also arise. ${ }^{7}$ Indeed, the most difficult choice during such an emergency would be to either accept a grim triage reality (in which not all patients receive a ventilator) or accept the fact that trying to save two patients with one ventilator could mean harming at least one of them.

To the best of our knowledge, no significant evidence is available to date on this topic, but very recently New YorkPresbyterian Hospital in the USA published a clinical guideline on this topic. ${ }^{8}$ To add to the controversy, however, a very recent consensus statement by several North American scientific societies discourages clinicians from connecting more than one patient to a single ventilator. ${ }^{7}$

\section{Author affiliations}

${ }^{1}$ Department of Medical and Surgical Sciences (DIMEC), Anesthesia and Intensive Care Medicine, Sant'Orsola-Malpighi Hospital, Alma Mater Studiorum University of Bologna, Bologna, Emilia-Romagna, Italy

${ }^{2}$ Dipartimento di Fisiopatologia Medico-Chirurgica e dei Trapianti, Università degli Studi di Milano, Milano, Lombardia, Italy

${ }^{3}$ Department of Anesthesia, Critical Care and Emergency, Fondazione IRCCS Ospedale Maggiore Policlinico Mangiagalli e Regina Elena, Milano, Italy

${ }^{4}$ Anesthesia and Intensive Care Medicine, Sant'Orsola Malpighi Hospital, Bologna, Italy

${ }^{5}$ Department of Emergency Medicine, Ascension St John Hospital and Medical Center, Detroit, Michigan, USA

${ }^{6}$ Covid-19 Commissioner, Emilia-Romagna Region, Bologna, Emilia-Romagna, Italy ${ }^{7}$ Department of Clinical, Integrated and Experimental Medicine (DIMES), Respiratory and Critical Care Unit, Sant'Orsola-Malpighi Hospital, Alma Mater Studiorum University of Bologna, Bologna, Italy

Contributors All authors contributed in designing and writing the paper and in testing the equipment. All authors read and approved the final version of this manuscript. 
Funding The authors have not declared a specific grant for this research from any funding agency in the public, commercial or not-for-profit sectors.

Competing interests None declared.

Patient consent for publication Not required.

Provenance and peer review Not commissioned; externally peer reviewed.

Open access This is an open access article distributed in accordance with the Creative Commons Attribution Non Commercial (CC BY-NC 4.0) license, which permits others to distribute, remix, adapt, build upon this work non-commercially, and license their derivative works on different terms, provided the original work is properly cited, appropriate credit is given, any changes made indicated, and the use is non-commercial. See: http://creativecommons.org/licenses/by-nc/4.0/.

ORCID iD

Tommaso Tonetti http://orcid.org/0000-0001-9676-3595

\section{REFERENCES}

1 Neyman G, Irvin CB. A single ventilator for multiple simulated patients to meet disaster surge. Acad Emerg Med 2006;13:1246-9.
2 Paladino L, Silverberg M, Charchaflieh JG, et al. Increasing ventilator surge capacity in disasters: ventilation of four adult-human-sized sheep on a single ventilator with a modified circuit. Resuscitation 2008;77:121-6.

3 Branson RD, Blakeman TC, Robinson BR, et al. Use of a single ventilator to support 4 patients: laboratory evaluation of a limited concept. Respir Care 2012:57:399-403.

4 Branson RD, Rubinson L. A single ventilator for multiple simulated patients to meet disaster surge. Acad Emerg Med 2006;13:1352-3.

5 Branson RD, Rubinson L. One ventilator multiple patients--what the data really supports. Resuscitation 2008:79:171-2.

6 Grasselli G, Pesenti A, Cecconi M. Critical care utilization for the COVID-19 outbreak in Lombardy, Italy: early experience and forecast during an emergency response. JAMA 2020. doi:10.1001/jama.2020.4031. [Epub ahead of print: 13 Mar 2020].

7 Consensus Statement on Multiple Patients Per Ventilator [Internet]. Available: https:/ www.sccm.org/Disaster/Joint-Statement-on-Multiple-Patients-Per-Ventilato [Accessed 7 Mar 2020].

8 Beitler JR, Kallet R, Kacmarek R, et al. Columbia University Vagelos College of Physicians \& Surgeons - New York-Presbiterian Hospital - ventilator sharing protocol: dual-patient ventilation with a single mechanical ventilator for use during critical ventilator shortages - version 4, March 272020 